\title{
UM PASSEIO PELA NARRATIVA DA BIOGRAFIA: CAZUZA A TRAJETÓRIA DE UM POETA
}

\author{
A TOUR OF THE BIOGRAPHY NARRATIVE: CAZUZA THE \\ TRAJECTORY OF A POET
}

\author{
Jonatan da Silva Ribeiro ${ }^{1}$
}

RESUMO: O jovem de classe média alta, dourado pelo sol de Ipanema, inicia na década de 1980 sua grande trajetória como poeta e um importante crítico social. Cazuza, como ficou conhecido, marcou a geração do rock brasileiro e por sua sagacidade, talento e ousadia para escrever temas corriqueiros da realidade da sociedade naquele período, conquistou um lugar privilegiado na galeria dos grandes artistas brasileiros.

Palavras-chave: Cazuza. Biografia. Narrativa.

SUMMARY: The young man from the upper middle class, golden by the sun of Ipanema, began his great career as a poet and an important social critic in the 1980s. Cazuza, as he became known, marked the Brazilian rock generation and, due to his wit, talent and daring to write common themes in the reality of society at that time, he conquered a privileged place in the gallery of great Brazilian artists.

Keywords: Cazuza. Biography. Narrative.

\section{INTRODUÇÃO}

Com o fim do regime ditatorial imposto pelos militares, em 1985, sobre a vitória de Tancredo Neves no Colégio Eleitoral, um clima de esperança envolve todo o Brasil, que vivera na expectativa e luta por uma democracia brasileira e volta das eleições diretas para a presidência da República.

Em pleno desenrolar da abertura política com um ar de bastante festa e comemoração, por conta do primeiro presidente civil, após vinte e um anos de governo dos militares, um grande evento ocorre pela primeira vez no Brasil: o Rock in Rio. Realizado na capital carioca, fora um grande festival com a participação de vários artistas e bandas, nacionais e internacionais. O grupo Barão Vermelho que tinha como vocalista Cazuza não ficou de fora e

\footnotetext{
${ }^{\mathrm{I}}$ Mestrando em Memória Social pelo Programa de Pós-Graduação da Universidade Federal do Estado do Rio de Janeiro. E-mail: jonatan31o@gmail.com.
} 
cantou os lindos versos. A alvorada da democracia com a música "Pro dia nascer feliz", tornase o hino daquele momento tão aguardado pela população e juventude brasileira.

Ao mesmo tempo, com escândalos de corrupção, a morte inesperada de Tancredo Neves, a posse de seu vice José Sarney, antigo colaborador da Ditadura Militar, as desigualdades sociais, a classe dominante cada vez mais favorecida, acabam por mostrar que a tão sonhada democracia brasileira não estaria funcionando muito bem, gerando uma enorme frustração na população do país. Cazuza mais uma vez mostra-se um porta-voz de sua geração, nas músicas "Ideologia", "Brasil” e o "Tempo não para." O artista revela todas as frustrações vividas pela sociedade, mostra as decepções e traz a discussão em tais canções os problemas sociais, políticos e econômicos vivenciados pela população brasileira e faz um convite bem ousado pedindo ao Brasil que mostre sua cara.

Promulgada em 1988, a nova Constituição brasileira seria em tese a mais democrática de todos os tempos no contexto político do Brasil, um enorme avanço para o país. O governo do então presidente Sarney foi marcado por grandes desafios e problemas, principalmente econômicos, altas inflações, planos de troca de moeda fracassados, levaram o país a uma grave crise, taxando os anos

8 o com o título de a "década perdida".

Esse trabalho se caracteriza como parte de uma apresentação de um trabalho de conclusão de curso a nível de graduação, sendo dados levantados com esse objetivo.

\section{CONTEXTUALIZAÇÃO TEÓRICA}

Duras críticas foram dirigidas a biografia desde a denúncia do "ídolo individual" de uma recém-fundada ciência sociológica, assim como a desqualificação do seu potencial cognitivo sob o argumento da "ilusão biográfica". A biografia sempre remeterá ao tema da unidade, coerência e sentido das experiências vividas por um indivíduo. (OLIVEIRA, 2017).

A questão crucial que se encontra no fundamento da questão biográfica é a da identidade pessoal, ou seja, a do sujeito ou o que da ação, condição de possibilidade para que uma existência possa ser narrada como história e por conseguinte biografada seria a de que um conjunto de ações possa ser atribuído ao mesmo agente ou sujeito no espaço temporal entre seu nascimento e sua morte.(OLIVEIRA, 2017).

A ambição de narrar vidas deu origem ao gênero biográfico, para Le Goff biografar não é tarefa fácil para um historiador, nenhuma história de vida é pensável sem o recurso da mediação narrativa que estaria na base da própria circunscrição do gênero. A noção moderna 
de biografia reforçou essa solução posto que se constituiu na confluência entre um sentido próprio (de relato de uma vida), nesse sentido uma vida não adquire sua verdadeira $e$ definitiva "realidade" senão por meio de e através do seu relato, que em suma é o que faz "surgir o inteligível do ocidental, o universo do singular, o necessário ou o verossímeis do episódio. (OLIVEIRA, 2017).

Não sendo um problema banal, a configuração das vidas individuais em histórias está longe de ser absolutamente evidente e foi justamente o pressuposto de que a existência do indivíduo pode ser organizado e narrada como um conjunto coerente de acontecimentos que esteve sob a mira do caráter "ilusório" e "fictício" do material biográfico. (OLIVEIRA, 2017).

A crítica ao "ídolo do individual” de uma recém-fundada ciência sociológica, traz uma certa desqualificação radical da pertinência cognitiva do gênero sob o estigma da "ilusão biográfica”. A recente polemização filosófica da narratividade e ataques dirigidos ao biográfico sempre tiveram por efeito perpetuar tanto uma noção esvaziada e empobrecida da narrativa, quanto a dimensão temporal da identidade de um indivíduo. (OLIVEIRA, 2017).

Para os historiadores profissionais empenhados nas afirmações do status científico da disciplina, uma via de solução estaria na postura de recusar a adesão radical firmando questionamento frente aos argumentos de defesa de qualquer defesa do valor cognitivo das histórias de vida no campo das ciências sociais. Pesquisas com relatos de sobreviventes, concluíam Pollak e Heinich, revelava o quanto era difícil a manutenção da "continuidade e coerência", tanto por um indivíduo como por um grupo, posto que isso resultaria "de um trabalho permanente de gestão da identidade", que consistiria em interpretar, ordenar e reprimir toda a experiência vivida, de modo a torná-la coerente em relação as experiências passadas. (OLIVEIRA, 2017).

A narrativa tem como característica descrever um percurso no tempo, seu plano para falar de seu título é principalmente cronológico, no mínimo partem de um primeiro elemento para chegarem a um segundo mais tardio e explicam como se fez a passagem do primeiro para o segundo.

Basta haver uma narrativa, para que haja dois acontecimentos ou situações por ordem no tempo, a narrativa adapta-se a qualquer cronologia, pode-se referir a qualquer objeto histórico, existe uma confusão frequente entre narrativa e História, a narrativa não é necessariamente linear ela adapta-se a múltiplos procedimentos literários que tornam a exposição mais viva e as vezes mais significativa, a narrativa presta-se a explicação das 
mudanças em uma busca das causas e das intenções, no entanto não é a única forma de exposição histórica.

A História é um texto acabado, um elemento recortado arbitrariamente no conjunto indefinido do continuum ilimitado da História, ela começa por uma questão, a construção do objeto histórico é determinante, a obra histórica constitui-se em primeiro lugar pelo recorte de seu objeto, tudo pode ser objeto da história. A obra histórica como relato ao narrar é que fornece a explicação, narrar é explicar.

Fundada em 1929,por Marc Bloch e Lucien Febvre a Revista dos Annales, foi um movimento de grande importância para a revolução da pesquisa acadêmica, os historiadores ligados a revista de forma explícita ou implícita, até então nunca haviam experimentado um eixo teórico claro. Bloch e Febvre eram unidos por um objetivo, que seria romper com a história factual, iam contra a história historicizante e quebravam elos com o positivismo em conceitos como os da racionalidade, progresso e ordem, que ainda eram muito fortes na historiografia. Esses intelectuais propunham uma história-problema, que nada mais era que o uso de hipóteses explícitas pelo historiador.(DOSSE, 1997). Criticando o velho método da História enquanto ciência, Lucien Febvre, traz a reflexão uma interessante metáfora:

Muitos historiadores, e dos bens formados e conscientes, o que é pior,
muitos historiadores se deixam ainda perder pelas próprias liçóes dos
vencidos de 1870 . Ah, eles trabalham muito bem! Eles fazem história do
mesmo modo que suas avós se dedicavam à tapeçaria. Pontinho por
pontinho. Eles são aplicados. Mas quando lhes perguntamos por que este
trabalho todo, a melhor resposta que conseguem dar, com um sorriso de
criança, é a palavra cândida do velho Ranke: "Para saber exatamente como
é que as coisas aconteceram". Com todos os detalhes, naturalmente (Lucien
Febvre, Contra o vento: manifesto dos novos Annales, 1946). (FEBVRE,
2orr, p. 82)

As hipóteses abertas serviam de fio condutor para a pesquisa, na concepção dos pesquisadores dos Anais, permanecendo a História uma ciência em construção. Os pensadores da Escola dos Annales, são caracterizados por uma tentativa de um "retorno as fontes", afirmam e fazem uma dura crítica em que os historiadores por muito tempo estiveram a serviço do poder real. (DOSSE, 1997).

A "história-problema", uma canção nova no alvorecer do século XX, continuou a ser uma canção útil em meados deste mesmo século, e mesmo além. Era ainda útil até mesmo evocar o velho inimigo, os "velhos metódicos" - os historiadores historizantes que dominavam o universo 
institucional francês em I87o - e que no texto manifesto de Febvre aparecem referidos na passagem sobre "as lições dos vencidos de 1870 ". (BARROS, p.311.2012).

Dão um valor científico do discurso historiográfico e ao deslocamento das fontes do historiador, que não mais pode contentar-se em privilegiar apenas documentos escritos, oriundos da esfera política, mas deve ampliar as fontes e os métodos. Para eles o historiador constrói seu próprio material, documentos em séries inteligíveis, que o próprio pesquisador integra em seu quadro teórico e adapta a sua pesquisa, fazendo uma confrontação dos documentos coletados com as hipóteses levantadas. "Nada caminha por si mesmo. Nada é dado. Tudo é construído.”(DOSSE, 1997).

\begin{abstract}
A revolução dos historiadores do Anais introduziu de uma vez por todas o problema no processo de construção do conhecimento histórico, definindo, portanto, a própria história como um fazer, uma fabricação conduzida pelo historiador. E mais: essa condução é ativa, isto é, o historiador conduz a elaboração da história com técnica e ideias. Desde então história científica é história problema. (CAVALCANTE, MAUAD. p-27.2012).
\end{abstract}

Goldenberg (2002), afirma que ao conhecer, caracterizar, analisar e elaborar sínteses sobre um objeto de pesquisa, o investigador dispõe de diversos instrumentos metodológicos. "o que determina como trabalhar é o problema que se quer trabalhar: só se escolhe o caminho quando se sabe aonde se quer chegar. (GOLDENBERG, p-I4, 2002).

\title{
3. METODOLOGIA
}

Cellard (2008,p.296, apud ALMEIDA; GUINDANI; SÁ-SILVA, 2009,p.7) mostra que ao privilegiar uma abordagem mais ampla de documento, a Escola de Annales, uma das linhas teóricas da História, estende para além do texto dos arquivos oficiais, a noção de documento. Desta forma, segundo o autor anteriormente citado, o conceito de documento passa a ser: "tudo o que é vestígio do passado, tudo o que serve de testemunho, é considerado como documento ou 'fonte"' (CELLARD, 2008, p. 296). E mais: "pode tratar-se de textos escritos, mas também de documentos de natureza iconográfica e cinematográfica, ou de qualquer outro tipo de testemunho registrado, objetos do cotidiano, elementos folclóricos, etc” (p. 297). 
Os dados coletados na imprensa municipal produzidos tanto pelos movimentos sociais como pelo proprietário do imóvel Renato Noronha, o Relatório da Comissão Municipal da Verdade, como documento oficial de Estado, o acervo de um dos principais movimentos sociais o (CPL), as reportagens da imprensa televisava como fontes testemunhais (FERRO, I993), foram imprescindíveis para a elaboração desse trabalho.

Oliveira (2007,p.69, apud ALMEIDA; GUINDANI; SÁ-SILVA, 2009,p.6) faz uma importante distinção entre pesquisa bibliográfica e pesquisa documental. Para essa autora a pesquisa bibliográfica é uma modalidade de estudo e análise de documentos de domínio científicos tais como livros, periódicos, enciclopédias, ensaios críticos, dicionários e artigos científicos. Como característica diferenciadora ela pontua que é um tipo de "estudo direto em fontes científicas, sem precisar recorrer diretamente aos fatos/fenômenos da realidade empírica” (p.69). Argumenta que a principal finalidade da pesquisa bibliográfica é proporcionar aos pesquisadores o contato direto com obras, artigos ou documentos que tratem do tema em estudo: "o mais importante para quem faz opção pela pesquisa bibliográfica é ter a certeza de que as fontes a serem pesquisadas já são reconhecidamente do domínio científico” (p. 69). Ela se posiciona sobre a pesquisa documental: "a documental caracteriza-se pela busca de informações em documentos que não receberam nenhum tratamento científico, como relatórios, reportagens de jornais, revistas, cartas, filmes, gravações, fotografias, entre outras matérias de divulgação" (p.69).

\section{RESULTADOS}

Agenor de Miranda Araújo Neto, nasceu no dia quatro de abril de 1958, no Rio de Janeiro, filho do grande produtor fonográfico João Araújo, respeitado presidente da gravadora Som Livre e da cantora Lucinha Araújo.

De classe média alta, Cazuza como ficou conhecido desde o ventre de sua mãe, foi criado nos encantos da zona sul carioca a menos de uma quadra do oceano Atlântico, sendo banhado diariamente pelo esplendoroso sol de Ipanema.

\footnotetext{
${ }^{2}$ Som Livre: gravadora musical brasileira, fundada em 1769.
} 
Agenor era um nome curto, com significado histórico, mas era feio. E, nessa época, na campanha do Jânio Quadros ele usava o slogan O Jânio vem aí, O Jânio vem aí. E não sei por que um certo dia acordei pensando assim: $O$ Cazuza vem aí, o Cazuza vem aí. No Nordeste, Cazuza significa "moleque", mas esse não era um nome comumente em minha casa. Lembro de um tio que tinha esse apelido. Comecei a brincar com o nome, antecipando uma alternativa para o garoto nascer." 3

Em 1963 é matriculado no Colégio Santo Inácio ${ }^{4}$, de padres jesuítas, uma das melhores escolas do Rio de Janeiro. Uma criança com traços bem rebeldes e um pré-adolescente com fases de bastante amor a transgressões. Cazuza apresentava algumas dificuldades em obedecer as regras e levar seus estudos a sério.

A vida escolar do Cazuza, na verdade nunca me deixou tranquila. Ele passou a desafiar minha autoridade à medida que crescia: passou a esconder o diário de classe e a rasgar boletins com notas baixas. ${ }^{5}$

Cazuza foi um garotinho tímido, mas arteiro. Sua atração por brincadeiras perigosas desafiava os limites. Quando estava muito quieto, não dava outra - o espírito incendiário se manifestara na certa. Sua aventura preferida era jogar álcool dentro do vaso sanitário e tocar fogo. ${ }^{6}$

Em virtude da profissão do pai como executivo da gravadora Som Livre, Cazuza como afirma sua mãe, foi criado no berço esplêndido da música popular brasileira, tendo contato com grandes nomes e artistas musicais da época.

Por isso desde pequeninho meu filho teve sua atenção naturalmente desperta para o mundo da música. Eu e João gostávamos de música, desde o namoro. Na época, eu estudava violão e em nossos encontros nos distríamos em tocar e cantar. Para Cazuza, aconteceu ainda de conhecer de perto os artistas que frequentavam nossa casa. Desde garoto, a paixão de Cazuza por Rita Lee era avassaladora. Não perdia nenhum de seus shows. Silvinha Telles foi minha colega de colégio e acompanhou Cazuza desde seu nascimento. Elis Regina, o viu crescer, assim como Jair Rodrigues, Novos Baianos, Caetano, Gil, Gal. Meu filho dizia que não tinha mitos, pois conviveu como todos eles. (ARAÚJO, 1997. p-82).

Sem a menor vocação para os esportes, desde muito cedo Cazuza desenvolveu uma habilidade formidável de inventar histórias, com uma imaginação muito aguçada e ao mesmo

${ }^{3}$ ARAÚJO, Lucinha. Só as mães são felizes. Editora Globo São Paulo.1997.

${ }^{4}$ Colégio Santo Inácio é uma instituição católica de ensino particular, fundada em 1903.

5 ARAÚJO, Lucinha. Só as mães são felizes. Editora Globo São Paulo.1997.

${ }^{6}$ ARAÚJO, Lucinha. Só as mães são felizes. Editora Globo São Paulo.1997. 
tempo nasce no garoto uma sinceridade muito forte, escancarada, o menino não possuía papas na língua. ${ }^{7}$

A partir dos quinze anos de idade, Cazuza se mostra um rebelde inconformado, simpatiza-se com o estilo hippie, passa a usar drogas e tem uma adolescência incontrolável, bem conturbada aos olhares da sociedade carioca conservadora. Cazuza não satisfeito sempre demonstrava a intenção de quebrar paradigmas tão fortes naquela sociedade tradicional e lança mais uma bomba agressiva a época: a de ser bissexual.

Com meu grupinho no Santo Inácio, nos considerávamos altamente intelectualizados. Éramos comunistas convictos, com onze, doze anos (risos). Desde aqueles tempos, eu era ótimo em redação. Agora mesmo, tenho pronto um livro de poesias. Falta só o editor. Outro dia achei um texto meu, escrito aos onze anos: uma redação engraçada, inocente, linda. Mas sempre fui péssimo em português. Tenho o dom de escrever, mas sou nulo em ortografia. ${ }^{8}$

Cazuza parecia possuir fascínio pela loucura e em cometer transgressões. Vez por outra seus pais tinham que buscá-lo na delegacia. Tal irreverência e sinceridade seriam marcas decisivas em sua grande trajetória como artista.

Com uma rotina de noitadas, bares e drogas, em 1978 o pai decide empregá-lo na Som Livre, no departamento de imprensa como divulgador, no qual tinha por tarefa escrever releases de artistas. Foi na gravadora que conheceu um de seus grandes parceiros, Ezequiel Neves", que o acompanharia até o dia de sua morte.

Em 1981, Cazuza se matricula no grupo de teatro Asdrúbal Trouxe o Trombone, ${ }^{10}$ dirigido por Perfeito Furtuna no Circo Voador. Nessas aulas, Cazuza se encontra com Bebel Gilberto, filha dos cantores João Gilberto e Miúcha, ela conta:

Com o Perfeito Fortuna, montamos a peça Paraquedas do Coração. Éramos muito animados e dedicados. Foi um sucesso a montagem e, depois dela começamos a nos mobilizar para conseguir um espaço onde o Circo Voador pudesse ser instalado. ${ }^{\text {II }}$

Nessa mesma época, o cantor Léo Jaime indica Cazuza para uma banda que estava começando, o Barão Vermelho. Sobre tal acontecimento Léo Jaime relata:

\footnotetext{
7 ARAÚJO, Lucinha. Só as mães são felizes. Editora Globo São Paulo.i997.

${ }^{8}$ ARAÚJO, Lucinha. Só as mães são felizes. Editora Globo São Paulo.1997.p-338.

9 Ezequiel Neves foi um bibliotecário, jornalista e produtor musical brasileiro. 29.12.1935 - 07.07.2010.

Io Asdrúbal trouxe o trombone foi um grupo teatral da década de 1970 com estilo cômico e anárquico.

" ARAÚJO, Lucinha. Só as mães são felizes. Editora Globo São Paulo.1997.p-136.
} 


\begin{abstract}
Uma noite, eu estava cantando num boteco de Botafogo e dois garotos me chamaram para um papo na casa deles no dia seguinte. Foram me pegar, me levaram para Rio Comprido e contaram que estavam formando um grupo e precisavam de um cantor. A banda se chamaria Barão Vermelho, e achei que era esporrenta demais. Fora que eu já tinha outras duas bandas. Aí falei que achava legal o lance deles, mas que tinha muito mais a cara de um amigo. Eles ficaram meio em dúvida, mas como tinham um show programado para dali a alguns dias, acabaram topando. Liguei para o Caju, o apelido como os amigos o chamavam, contei a história e dei o endereço e a hora do ensaio. Ele falou que eu tava pirado, que ele não conhecia os caras, que a dele não era essa e coisa e tal. Eu disse que se fosse o caso, ia com ele, mas eu já tinha prometido aos garotos. Não fui, mas ele foi." ${ }^{12}$
\end{abstract}

Maurício Barros no teclado, Guto Goffi na bateria, Dé no baixo, Roberto Frejat na guitarra e Cazuza como cantor formavam a banda Barão Vermelho. Em ensaios de garagem, o grupo com letras fortes e marcantes conseguiam impactar a plateia nos primeiros pequenos shows que realizavam. Cazuza cria uma empatia muito grande por Frejat, que seria seu eterno companheiro de música.

Uma fita amadora gravada pelo grupo chega as mãos de Ezequiel Neves, que na época era produtor musical da Som Livre. Assim começa a carreira de sucesso do Barão Vermelho, de Cazuza e do próprio Ezequiel Neves (Zeca), sobre tal fato Zeca afirma:

Ficamos todos bastante impressionados com as letras das músicas do Barão. Tinha muita coisa escrita em português errado, mas uma linguagem totalmente moderna, atualíssima, falando de garotada, de dor de corno. Lembro que liguei para Lucinha e lhe disse: "Recebi uma fita de um grupo em que seu filho é vocalista. Quem escreve as letras? E ela me respondeu: “É o meu filho!”. Então eu disse:”Lucinha, prepare-se porque seu filho é genial". ${ }^{13}$

No dia 27 de novembro de 1982 o grupo lança seu primeiro LP, tendo como músicas mais importantes e bem aceitas: "Bilhetinho azul", "Todo amor que houver nessa vida", "Ponto Fraco" e

"Dow em mim". Mesmo com uma vendagem não muito significativa, apenas oito mil cópias, a banda já possuía certos admiradores como Caetano Veloso que deixou sua opinião sobre o disco.

\footnotetext{
${ }^{12}$ ARAÚJO, Lucinha. Só as mães são felizes. Editora Globo São Paulo.1997·p-139.

${ }^{13}$ ARAÚJO, Lucinha. Só as mães são felizes. Editora Globo São Paulo.1997.pI45. ${ }^{13}$ ARAÚJO, Lucinha. Só as mães são felizes. Editora Globo São Paulo.i997.p-is6.
} 
E em São Paulo, passeando de carro com a Patrícia Casé, escutei "Bilhetinho Azul" e chorei. Chorei dentro do carro. Fiquei apaixonado, maravilhado. Depois ouvi o resto do disco do Barão e, até hoje, é um dos meus favoritos. ${ }^{13}$

Em I983 Caetano Veloso no palco do Canecão estreava seu novo disco "Uns" e canta “Todo amor que houver nessa vida", elogia Cazuza defendendo ser ele "o melhor poeta de sua geração”. O disco do Barão Vermelho, entretanto, não conseguia emplacar. Nesse mesmo ano, o grupo retorna ao estúdio e grava o segundo LP, com Ezequiel Neves na produção. Entre as canções estava "Pro dia nascer feliz", que fora gravada também por Ney Matogrosso e impulsionada nas rádios.

No ano de I984, a banda lança seu álbum de maior sucesso "Maior Abandonado" com doze faixas incluindo "Bete Balanço" que foi tema de cinema e levou o Barão a conhecimento do grande público de norte a sul do Brasil. A essa altura, Cazuza já era reconhecido como um grande poeta do rock brasileiro e um letrista muito importante para sua geração.

O rock é a ideia da eterna juventude. Quando descobri o rock, descobri também que podia desbundar. O rock foi a maneira de eu me impor ás pessoas sem ser o gauche - porque de repente virou moda ser louco. Eu estudava num colégio de padre onde, eu era a escória. Então quando descobri o rock, descobri a minha tribo: ali eu ia ser aceito! E rock para mim não é só música, é atitude mesmo, é o novo! Quer coisa mais nova que o rock? O rock fervilha, é uma coisa que nunca pode parar. O rock não é uma lagoa é um rio. $\mathrm{O}$ rock é a vingança dos escravos. ${ }^{\mathrm{I}}$

Em 1985, o grupo se apresenta no Rock in Rio, um grande festival de rock promovido no Rio de Janeiro, com a participação de grandes nomes nacionais internacionais. Barão Vermelho encerra o show, com mais de 60.00o pessoas cantando a música "Pro dia nascer feliz" e Cazuza envolto na bandeira do Brasil, um marco na história da música brasileira e dos festivais.

Sob o canto roqueiro e esperançoso de Cazuza, então vocalista da banda Barão Vermelho, a canção refletia o entusiasmo político dos participantes do evento, bem como a perspectiva de um novo rumo para a vida nacional. Sob intenso aplauso do público, Cazuza, envolto pela bandeira brasileira, mudaria o refrão de sua composição e cantaria: "Pro Brasil nascer feliz". O ato de Cazuza representava e anunciava para todo o país que o rock e os roqueiros dos anos 80 também estavam antenados com o processo político brasileiro. ${ }^{15}$

\footnotetext{
${ }^{14}$ ARAÚJO, Lucinha. Só as mães são felizes. Editora Globo São Paulo.1997·p-344.

is ENCARNAÇÃO, Paulo Gustavo. Rock in Rio - Um festival (Im)pertinente a música brasileira e a redemocratização nacional.. Unesp - FCAls - CEDAP, v.7, p-348-368.2011. p-35I.
} 
Frequentes brigas e mal estar passaram a afligir o grupo e Cazuza já não estava mais satisfeito em estar na banda, que agora estava com suas músicas arrebentando em todas as paradas do Brasil. Com o LP “Maior Abandonado" tendo mais de roo mil cópias vendidas, Cazuza decide seguir carreira solo.

Cazuza e o Barão Vermelho. Aliás, assim mesmo, nessa ordem, é que a mídia passou a se referir ao grupo. Era evidente a aura própria que meu filho exibia, mesmo dividindo a cena com seus companheiros. Do seu ponto de vista, ele dizia se sentir cansado de seguir as regras da banda, de limitar seu trabalho de composição ao estilo do grupo e, mais ainda, de suportar dividir. Acostumado, desde que nasceu, a ser o único dono de seu território, Cazuza tinha uma enorme dificuldade em compartilhar. Além disso, suas bebedeiras e loucuras passaram a incomodar - e bastante - os outros barões, até mesmo seu amigo Frejat. ${ }^{16}$

O primeiro álbum da carreira solo de Cazuza é lançado em 1985, "Exagerado" com mais de 750 mil cópias vendidas. $\mathrm{O}$ artista tem sua primeira internação com uma febre altíssima, faz o teste de HIV que na época dera negativo.

Meu primeiro disco solo é um trabalho onde eu estou me expondo muito,
quis mudar um pouco a temática. Na época do Barão Vermelho eu era tido
como letrista que cantava fossa, a dor de cotovelo. Este disco está um pouco
mais para cima, tem músicas onde olho menos para o umbigo. Neste disco,
eu quis fazer homenagens a poetas que gosto, está um trabalho diferente.
Tem uma música bem romântica de uma separação, mas que não é dor de
cotovelo. Tem músicas desesperadas, mas é um desespero mais universal,
não é aquela coisa de dor a dois. ${ }^{17}$

Em uma entrevista na época, Cazuza deixa clara sua posição política e define o disco "Exagerado": "Exagerado é um disco agressivo, mas eu acho que a gente tem que ser agressivo, porque estamos numa época muito agressiva, a direita está agressiva." ${ }^{18}$

Seu segundo disco solo foi o "Só se for a dois", contendo onze faixas e mais de 6oo mil cópias vendidas, lançado em março de 1987 no Teatro Ipanema pela ilustre gravadora Polygram. Nesse compacto, o artista já começa a mostrar seu outro lado que não era somente o rock e inicia uma ponte com a MPB. Cazuza já vinha sentindo alguns sintomas que indicavam que sua saúde não estava bem.

${ }^{16}$ ARAÚJO, Lucinha. Só as mães são felizes. Editora Globo São Paulo.1997.p.i76.

${ }^{17}$ ARAÚJO, Lucinha. Só as mães são felizes. Editora Globo São Paulo.1997.p-346.

${ }^{18}$ ARAÚJO, Lucinha. Só as mães são felizes. Editora Globo São Paulo.1997.p-349. 
“O disco Só se for a dois me permitiu usar uma coisa não rock 'n' roll. Eu tenho esse lado de cantor de churrascaria." ${ }^{19}$ Aos 29 anos, em 1987 Cazuza descobre ser portador da Síndrome da Imunodeficiência Adquirida (AIDS). Embarca para Boston nos Estados Unidos e inicia um tratamento com o dr. Sheldon Woff, chefe da clínica médica do New England Medical Center e membro do programa de combate a Aids.

Retornando do Estados Unidos, Cazuza estava muito mais amadurecido por conta da doença e diz ter visto a cara de morte e que ela estava bem viva em I988. Lança seu mais novo disco "Ideologia", consagrando para sempre sua carreira enquanto poeta e crítico social.

O disco "Ideologia" foi o terceiro álbum solo do artista, sendo considerado o seu melhor trabalho de estúdio, do qual ganhou o Prêmio Sharp. ${ }^{20}$ Cazuza demonstrava ter pressa em gravar, compor e deixar seu legado. "Brasil", "Ideologia" e "Faz parte do meu show", são as principais canções e definem a obra do cantor.

Ideologia fala da minha geração sem ideologia, compactada entre os anos 196o e os dias de hoje. Eu fui criado em plena ditadura, quando não se podia dizer isso ou aquilo, em que tudo era proibido. Uma geração muito desunida. Nos anos 1960, as pessoas se uniam pela ideologia. "Eu sou da esquerda, você é de esquerda? Então a gente é amigo. A minha geração se uniu pela droga: ele é careta e ele é doidão. Droga não é ideologia, é uma opção pessoal. A garotada teve sorte de pegar a coisa pronta e aí pode decidir o que fazer pelo país, embora, do jeito que o Brasil está, haja muita desesperança. ${ }^{21}$

Com mais de 500 mil cópias vendidas, o disco "Ideologia" registra todas as frustrações da geração de Cazuza, que se torna um grande porta-voz dos sentimentos, expectativas e pensamentos daquela sociedade. A turnê de lançamento do álbum fora dirigida pelo cantor Ney Matogrosso que ensina novas técnica para Cazuza em relação ao palco e utilização da voz.

Cada vez mais debilitado pela doença, Cazuza não hesita em expor suas opiniões políticas e é acometido por avalanches de verdades que ele decide defender; afirma ser socialista e que a única maneira de se resolver os problemas de um país de terceiro mundo é através do socialismo.

Os problemas do Brasil parecem ser os mesmos desde o descobrimento. A renda concentrada, a maioria da população sem acesso a nada. A classe

\footnotetext{
${ }^{19}$ ARAÚJO, Lucinha. Só as mães são felizes. Editora Globo São Paulo.1997.p-35o.

${ }^{20}$ Prêmio Sharp: premiação da música popular brasileira idealizado em 1987.

${ }^{21}$ ARAÚJO, Lucinha. Só as mães são felizes. Editora Globo São Paulo.1997·p-356.
} 
média paga o ônus de morar num país miserável. Coisas que, parece vão continuar para sempre. Nós teríamos saída, pois nossa estrutura industrial até permitiria isso. O problema do Brasil é a classe dominante, mais nada. Os políticos são desonestos. A mentalidade do brasileiro é muito individualista: adora levar vantagem em tudo. ${ }^{22}$

Educação é a única coisa que poderia mudar este quadro. Brasileiro é grosso e maleducado, porque não pensa na comunidade, joga lixo na rua, cospe, não está nem aí. Esse espirito comunitário viria com a cultura. Acho que o socialismo talvez possa trazer esse acesso a cultura de massas. Fazer como o Mao Tsé-tung fez com a China. Educar todo mundo a força. Temos que estudar, ler ter acesso a livros. ${ }^{23}$

Em atitude de coragem, num período de fortes discriminações e preconceitos, Cazuza decide assumir em público a sua doença, sendo o primeiro artista e pessoa pública a assumir ser portador do vírus da Aids. O cantor ainda afirma que a doença caiu como uma "luva no modelinho perfeito da direita e da Igreja", as quais ele diz com todas as letras possuir "desprezo" alega ainda que a direita é "mesquinha", auto declarando-se de esquerda por gostar de dividir as coisas. ${ }^{24}$

Há algum tempo eu deixei de esconder a aids. Acho que graças à Marília Gabriela, que me deu um toque. Depois que ela me falou que não fazia sentido o fato de eu negar o vírus com minha posição liberal como artista. Aí eu pensei, vi que ela tinha razão e achei melhor parar de esconder. ${ }^{25}$

No mês de janeiro de 1989, Cazuza lança seu quarto álbum solo "O tempo não pára" com mais de 500 mil cópias vendidas, contendo dez faixas. Na música o "Tempo não pára", Cazuza expõe as realidades e dificuldades de ser brasileiro.

Em agosto de 1989 lança seu quinto álbum "Burguesia", contendo vinte faixas, inclusive "Burguesia", na qual critica a classe dominante e afirma que "a burguesia fede". Muito enfraquecido pela doença, o cantor em uma cadeira de rodas, não mede esforços para as gravações no estúdio e seu perfeccionismo aumenta ainda mais. "Cazuza estava tão determinado a concluir esse trabalho e tinha tanta pressa que chegou a gravar deitado no sofá do estúdio, sob efeito de 39 graus de febre." ${ }^{26}$

\footnotetext{
${ }^{22}$ ARAÚJO, Lucinha. Só as mães são felizes. Editora Globo São Paulo.1997.p-354-355.

${ }^{23}$ ARAUUJO, Lucinha. Só as mães são felizes. Editora Globo São Paulo.1997.p-355.

${ }^{24}$ ARAÚJO, Lucinha. Só as mães são felizes. Editora Globo São Paulo.1997.p-367.

${ }^{25}$ ARAÚJO, Lucinha. Só as mães são felizes. Editora Globo São Paulo.1997·p-37o.

${ }^{26}$ ARAÚJO, Lucinha. Só as mães são felizes. Editora Globo São

Paulo.1997.p-266. ${ }^{27}$ Veja: revista semanal brasileira publicada pela Editora

Abril, criada em 1968 .
} 
No dia 26 de abril de 1989, Cazuza é bombardeado pela revista Veja ${ }^{27}$, a qual ele havia cedido

uma entrevista dias antes. "Cazuza uma vítima da Aids agoniza em praça pública" e uma foto do cantor já bem debilitado como capa da edição. Sem a menor consideração, a reportagem afirma que Cazuza estava "definhando" um pouco a cada dia rumo ao fim. A matéria fora totalmente tendenciosa e buscou ridicularizar o artista, tocando em assuntos como bissexualidade, drogas, bebidas, bares, induzindo seu trabalho artístico e sua legião de fãs a uma concepção totalmente negativa a respeito dos acontecimentos.

A revista não hesitou em mostrar todas as dificuldades e debilidades que vinham passando Cazuza, taxando-o como drogado, alcoólatra, promiscuo sexual e um possível transmissor do vírus da Aids, além de ferir com crueldade seu trabalho enquanto artista.

\begin{abstract}
Cazuza não é um gênio da música. É até discutível se sua obra irá perdurar, de tão colada que está no momento presente. Não vale igualmente, o argumento que sua obra tende a ser pequena devido à força do destino: quando morreu de tuberculose em 1937, Noel Rosa tinha 26 anos, cinco a menos que Cazuza, e deixou compostas nada menos que 213 músicas, dezenas delas obras-primas que entraram pela eternidade afora. Cazuza não é Noel, não é um gênio. É um grande artista, um homem cheio de qualidades e defeitos que tem a grandeza de alardeá-los em praça pública para chegar a algum tipo de verdade.(VEJA,1989). ${ }^{27}$
\end{abstract}

Após ler a matéria, Cazuza é gravemente internado na clínica São Vicente e fica bastante comovido com o apoio de seus fãs. Em jornais e revistas é publicada uma cartaresposta de Cazuza com o título "Veja a agonia de uma revista".

A leitura da edição da Veja que traz meu retrato na capa produz em mim -
e acredito em todas as pessoas sensíveis e dotadas de um mínimo de espírito
e solidariedade - um profundo sentimento de tristeza e revolta. Tristeza
por ver essa revista ceder a tentação de descer ao sensacionalismo, para me
sentenciar à morte em troca da venda de alguns exemplares a mais. Se os
seus repórteres e editores tinham de antemão determinado que estou em
agonia, devia quando nada, ter tido a lealdade e franqueza de o anunciar para
mim mesmo, quando foram recebidos cordialmente em minha casa. Mesmo
não sendo jornalista, entendo que a afirmação de que sou um agonizante
devia estar fundamentada em declaração dos médicos que me assistem,
únicos, segundo entendo, a conhecerem meu estado clínico e, portanto, em
condiçães de se manifestarem a respeito. A Veja não cumpriu esse dever e,
com arrogância, assume o papel de juiz do meu destino. Esta é a razão da
minha revolta. Não estou em agonia, não estou morrendo. Posso morrer a
qualquer momento, como qualquer pessoa viva. Afinal, quem sabe com
certeza o quanto vai durar? Mas estou vivíssimona minha luta no meu

${ }^{27}$ ARAÚJO, Lucinha. Só as mães são felizes. Editora Globo São Paulo.1997·p-269. 
trabalho, no meu amor pelos meus seres queridos, na minha música-e, certamente, perante todos os que gostam de mim. ${ }^{28}$

No dia 7 de julho de 1990, Cazuza falece no Rio de Janeiro aos 32 anos em decorrência de complicações do vírus da Aids. Deixa uma obra vasta e parcerias com grandes nomes da música brasileira como Gilberto Gil, Lobão, George Israel, Arnaldo Brandão. "Em oito anos de carreira Cazuza deixou 126 músicas gravadas por ele, 34 por outros intérpretes e mais de 60 inéditas." ${ }^{29}$

\section{CONCLUSÕES}

De acordo com Beatriz Sarlo o passado é sempre conflituoso, estando em constante concorrência a memória e a História, nem sempre a História consegue acreditar na memória e a memória desconfia de uma reconstituição que não coloque em seu centro os direitos da lembrança. Nesse

sentindo a lembrança não permite ser deslocada, pelo contrário ela é constituída por uma decorrente perseguição, por nunca estar completa. (SARLO, 2007).

A lembrança insiste porquê de certa maneira é soberana e incontrolável, precisando sempre do presente, que é o seu tempo próprio para lembrar. O tempo passado, de acordo com Sarlo não pode ser eliminado e é um perseguidor capaz de escravizar ou libertar. (SARLO, 2007).

"Penso no que vai ficar de mim" foi uma das últimas frases ditas por Cazuza. Sua carreira artística conseguiu consolidar-se e eternizar-se na história da música e arte brasileira.

Os tempos de felicidade e esperança, por conta do fim do regime militar e abertura política no Brasil, em clima completamente festivo foi muito bem cantado por Cazuza e sua banda no Rock in Rio, representando assim a satisfação do povo brasileiro em ver o país tomar outros rumos em sua política até então autoritária.

Decepções começaram a surgir quando Tancredo Neves, o então presidente eleito pelo voto indireto falece e fica o cargo da presidência da República nas mãos de seu vice, José Sarney, que colaborava com a Ditadura Militar.

Os anos de 1980 foram repletos de novidades no Brasil, a redemocratização política, o Rock in Rio, a nova Constituição de 1988. Uma década de altas inflações e grandes decepções por ser brasileiro, levam Cazuza a gravar músicas que contam e recontam a realidade do país.

${ }_{28}$ ARAÚJO, Lucinha. Só as mães são felizes. Editora Globo São Paulo.1997·p-272.

${ }^{29}$ ARAÚJO, Lucinha. Só as mães são felizes. Editora Globo São Paulo.1997.p-269. 
"Ideologia", "Brasil" e o "Tempo não para" escancaram a falta de motivação por parte da população, os escândalos de corrupção, as altas de inflações e a grande desigualdade social vivida no período.

\section{REFERÊNCIAS BIBLIOGRÁFICAS}

ARAÚJO, Lucinha. Só as mães são felizes. Editora Globo São Paulo.1997.

CORREAA, Maria Letícia. História do Brasil IV.v2 /Maria Letícia Corrêa, Mônica Piccolo Almeida -Rio de Janeiro: Fundação Cecierj, 2013.

LE GOFF, J. 1994. História e memória. 3. ed., Campinas, SP: Ed. Unicamp. NORA, P. 1993. "Entre memória e história: a problemática dos lugares". Projeto História, n. Io, p. 7-28.

SARLO, BEATRIZ. Tempo Passado: cultura de memória e guinada subjetiva. São

Paulo: Companhia das Letras; Belo Horizonte: UFMG, 2007.

http://www.edufrn.ufrn.br/bitstream/123456789/711/r/A\%20QUEST\%C3\%83\%C2\%83O\%2 oDO\%2.HISTORIADOR.\%20Doze\%2oli\% $\mathrm{C}_{3} \% 83 \% \mathrm{C}_{2} \% \mathrm{~A} 7 \% \mathrm{C}_{3} \% 83 \% \mathrm{C}_{2} \% \mathrm{~B}_{5}$ es\%2.0sobre\%2 oa\%2ohist\% $\mathrm{C}_{3 \%}$ 83\%C2\%B3ria.\%20PROST,\%20Antoine.\%202008.pdf

Fontes

FREJAT, CAZUZA. Pro dia nascer feliz. In: Barão Vermelho 2. Rio de Janeiro. Som Livre, 1983.

Pro dia nascer feliz. Cazuza e Frejat. Barão Vermelho 2. Som Livre. 1983.

Rock in Rio Barão Vermelho 1985. Produzido por Barão Vermelho - Coordenação Geral do DVD: Marco Mazzola. MZA music, 2007, relançamento 2011. 